Acta Horticulturae et Regiotecturae - Special Issue

Nitra, Slovaca Universitas Agriculturae Nitriae, 2016, pp. 1-4

\title{
COLOURATION OF APPLE CV. ‘BRAEBURN' GROWN UNDER ANTI-HAIL NETS IN CROATIA
}

\author{
Goran FRUK ${ }^{1 *}$, Mladen FRUK', Marko VUKOVIĆ1', Josip BUHIN'1, \\ Mushtaque Ahmed JATOI ${ }^{1,2}$, Tomislav JEMRIĆ \\ 'University of Zagreb, Croatia \\ ${ }^{2}$ Shah Abdul Latif University, Date Palm Research Institute, Khairpur, Pakistan
}

\begin{abstract}
Four anti-hail and anti-insect nets (red, white and yellow anti-hail and Stop Drosophila Normal) were used on apple cv. 'Braeburn' grown in northern Croatia in order to evaluate their effect on fruit colouration that was measured with the colorimeter (expressed as: $L^{*}$ - lightness, $a^{*}$ - yellow/blue b* - green/red) on two sides of fruit ("green" side and "red" side), and also they were used in order to evaluate their effect on the coloured surface percentage, apart from their anti-hail and pest damage protection properties. The fruits were harvested on $12^{\text {th }}$ October 2015 . Most differences were found between the fruit grown under the white anti-hail net and the fruit grown without the anti-hail net. Colour value "a*" was lower on the red side of the fruit under the white net in comparison with the red net. On the green side," $\mathrm{a}^{*}$ "value was lower and " $\mathrm{L}^{*}$ "value was higher under the white net in comparison with control fruit. Different net colour had no influence on total colour difference. Regarding to the colouration, differences among the nets are found in classes $0-25 \%$ and $50-75 \%$ of skin coloured fruit. The fruit grown under the white nets had the higher percentage of fruit in class $0-25 \%$ than those grown without the net. The lower share of fruit in class $50-75 \%$ of skin colouration was recorded under the white net than under the red net or in the control fruit. Colouration index was lower in the fruit grown under the white net than in the control fruit. It can be concluded that the white anti-hail net promotes ripening, but at the same time it decreases red colouration. No significant differences in fruit colour have been found in the fruit grown under the red, yellow and Stop Drosophila Normal nets. Some accepted colour parameters such as a*/b* ratio are not appropriate for describing colour changes in 'Braeburn' apple in this study.
\end{abstract}

Keywords: apple fruit quality, photo-selective netting, colouration, production

The apple is the most important fruit crop in Croatia. Usual apple pest management system includes from 20 to 30 pesticide sprays per season, and in extreme years or in the other countries such as France it can be from 35 to 40 applications per season. Most of these treatments are performed against Codling moth (Cydia pommonela L.) (Sauphanor et al., 2012). As is awareness on impact of agrochemicals on human health and environment in constant growth, so are the alternative pest management strategies investigated. These strategies include biocontrol agents or pheromones for mating disruption and confusion (Arthurs et al., 2007; Witzgall et al., 1999). In recent times, the use of physical barrier for pests such as exclusion net is used. For this purpose, the anti-hail nets are often used (Sauphanor et al., 2012). Such technology significantly reduces the use of chemicals in orchard. However, anti-insect nets may affect internal fruit quality and fruit colour, due to their effect on light spectra. One of the most important fruit quality characteristic is fruit skin colour which has great impact on consumer's preferences (Pathare et al., 2012; Peng and Moriguchi, 2013). Among numerous factors affecting skin colour (genetic factor, chemical, biochemical, microbial and physical changes during growth, maturation, postharvest handling and processing), environmental factors such as temperature (especially night and day amplitude), heat and cold stress, relative air humidity and light (Iglesias et al., 2002; Jakopic et al., 2007; Pathare et al., 2012; Ubi et al., 2006; Zhang et al., 2016) have strong impact on it. Previous studies showed that chlorophyll, carotenoids and anthocyanins content and their proportions determine fruit colour and appearance, and they often serve as fruit quality markers (Abbott, 1999; Nagy et al., 2016; Saure, 1990; Solovchenko et al., 2005). Therefore, the aim of this study is to show how the different colour of the exclusion nets influences apple fruit skin colour and ripening.

\section{Material and methods}

\section{Plant material}

The measurements were carried immediately after the harvest on $12^{\text {th }}$ October 2015 on the 7-years-old 'Braeburn' apple trees grafted on M9 rootstock, grown in the productive orchard near Krapina (northwest of Croatia). The trees were covered with four types of exclusion nets after flowering, and uncovered trees served as control ones. The load of crop on individual trees was similar and did not significantly differ among the treatments. 


\section{Exclusion nets}

Four exclusion nets were used: Agritenax white, Agritenax yellow and Agritenax red anti-hail nets produced by Tenax S.r.l,Italy and Stop Drosophila Normal (pearl colour) from Artes Politecnica, Italy. Density of Agritenax net was $2.4 \times$ $4.8 \mathrm{~mm}$, and density of Stop Drosophila Normal net was $0.9 \times 1 \mathrm{~mm}$.

Each exclusion net was placed randomly on three places in orchard, and they were used as 3 replications with five trees per each replication.

\section{Fruit colour measurement}

Colour measurement was performed on the 30 randomly harvested fruit under each net and replication. Thus, in total 90 fruit $(3 \times 30$ fruit) per each exclusion net and 90 fruit $(3 \times 30$ fruit) as control fruit were used for colour measurement.

Fruit colour was measured by ColorTec-PCM Plus $30 \mathrm{~mm}$ Benchtop Colorimeter (ColorTec Associates, Inc., USA).

Fruit chromaticity was measured in CIE L*a*b* colour space coordinates (Commission Internationale d'Eclairage). The colorimeter was calibrated with a white and black standard calibration plates before the use. In CIE L*a*b* colour space, the $L^{*}$ value corresponds to a dark-bright scale and it represents the relative lightness of colours with a range from 0 to $100(0=$ black, $100=$ white). The $a^{*}$ and $b^{*}$ scales extend from -60 to 60 where $a^{*}$ is negative for green and positive for red and $b^{*}$ is negative for blue and positive for yellow.

As 'Braeburn' apples are not uniformly coloured, so colour was measured at two points on the fruit, on the reddest point (additional skin colour) and on the greenest point (background skin colour).

\section{Colour indices}

Colour indices $(C l)$ were measured according to Pathare et al. ( 2012 ) by formula:

$$
C l=\frac{a^{*}}{b^{*}}
$$

\section{Total colour difference}

Total colour difference was calculated according to Pathare et al. (2012) by formula:

$$
\Delta E=\sqrt{\Delta L^{* 2}+\Delta a^{* 2}+\Delta b^{* 2}}
$$

Colour differences were calculated in comparison to colour parameters of control fruit.

\section{Fruit colouration}

Fruit colouration was determined as a percentage of fruits classified into 4 classes depending on percentage of coloured fruit skin $(0-25 \%, 25-50 \%$, 50-75\% and 75-100\%).

\section{Colouration index}

Colouration index $(C I x)$ was depending on number of fruit in colouration classes and it was calculated by formula:

$C l x=\frac{C 1 \times 1+C 2 \times 2+C 3 \times 3+C 4 \times 4}{C 1+C 2+C 3+C 4}$

where:

C1 - number of fruit with $0-25 \%$ fruit skin coloured

C2 - number of fruit with $25-50 \%$ fruit skin coloured

C3 - number of fruit with $50-75 \%$ fruit skin coloured

C4 - number of fruit with $75-100 \%$ fruit skin coloured

\section{Statistical analyses}

The colour data were statistically analysed with the SAS 9.3 Statistical package, using the one-way analysis of variance (ANOVA) and LSD test. $P$-values of less than 0.05 were statistically considered to be significant.

\section{Results and discussion}

Beside temperature difference between day and night, and relative air humidity, apple colouration is affected also by the intensity and the spectrum of sunlight. The anti-hail nets are often reducing the light intensity, and so they are reducing the red colouration. This is especially true for the dark coloured nets such as black ones (Guerrero et al., 2002; Jakopic et al., 2007). As 'Braeburn' apple is characterised by light-green to yellow background colour with reddish tones on most of the surface, so the colour was measured on two sides of fruit (the greenest - background colour, and the reddest - additional colour) by CIE L*a*b* colour space.

Parameter $L^{*}$ (lightness) showed statistical difference only on green side of apple where $L^{*}$ value was higher in the fruit grown under the white nets in comparison to the control fruit (grown without the nets). Statistical difference between these two treatments was also found in parameter $a^{*}$ (green-red parameter) which was lower in the fruit grown under the white net than in the fruit grown without the nets (Figure 1). Additionally, on the red side of fruit, it was found that a* parameter was lower in the fruit grown under the white net than in the fruit grown under the red net (Figure 2). Parameter b* (blue-yellow) did not show any significant difference on both sides of fruit (green and red

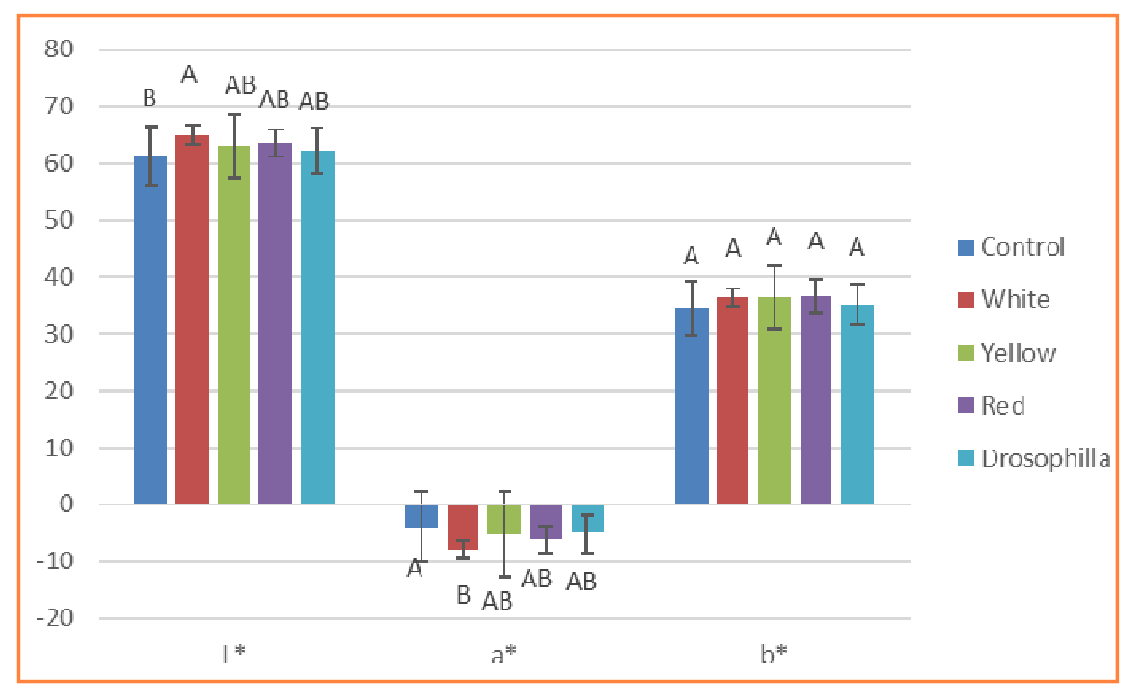

Figure $1 \quad \mathrm{CIE} \mathrm{L*} \mathrm{a}^{*} \mathrm{~b}^{*}$ colour values for the green side of apple $\mathrm{cv}$.'Braeburn' grown under the white, yellow, red and Stop Drosophila Normal nets and without the net

Note: Means inside one colour parameter followed with the same letter are not significantly different (LSD test at $p \leq 0.05$ level) 


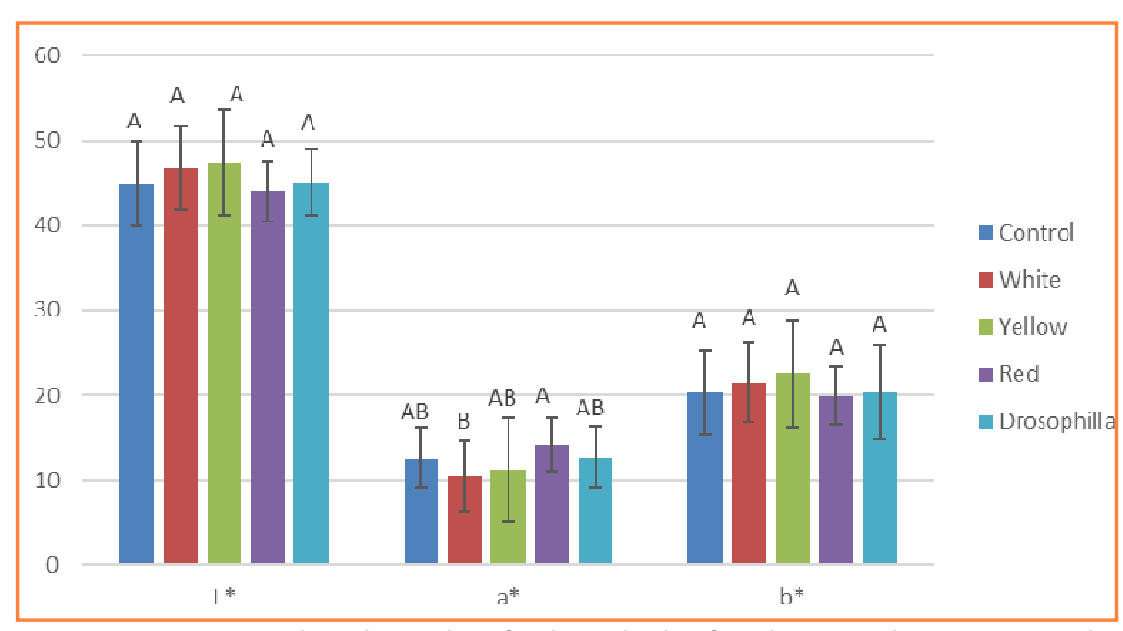

Figure 2 CIE L*a*b* colour values for the red side of apple cv. 'Braeburn' grown under the white, yellow, red and Stop Drosophila Normal nets and without the net Note: Means inside one colour parameter followed with the same letter are not significantly different (LSD test at $p \leq 0.05$ level)

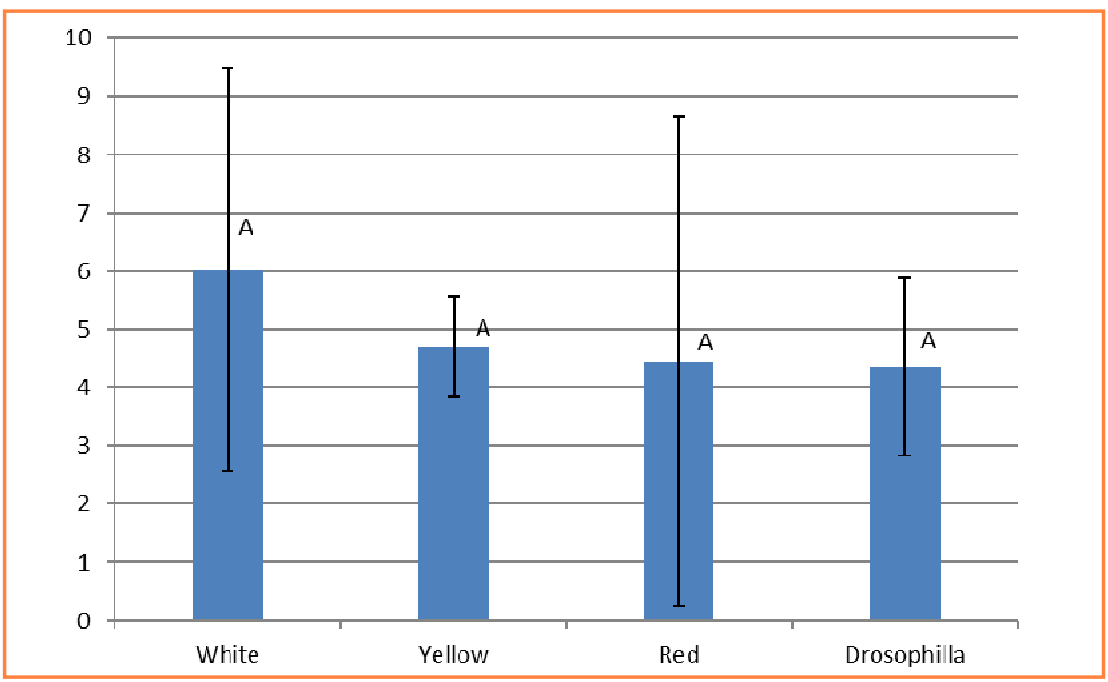

Figure 3 Total colour difference between the control fruit and the fruit grown under the white, yellow, red and Stop Drosophila Normal net on the green side of apple cv. 'Braeburn

Note: Means followed with the same letter are not significantly different (LSD test at $p \leq 0.05$ level)

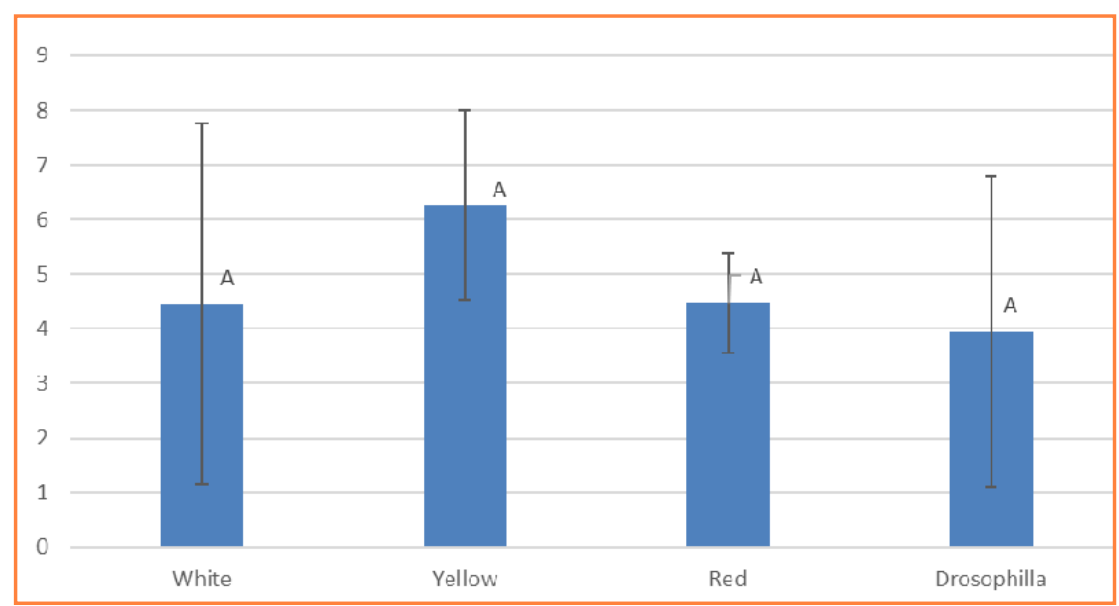

Figure 4 Total colour difference between the control fruit and the fruit grown under the white, yellow, red and Drosophila net on the red side of apple cv. 'Braeburn'

Note: Means followed with the same letter are not significantly different (LSD test at $p \leq 0.05$ level) side) between the fruit grown under the nets and the control fruit. This shows that the white nets can cause lighter skin colours in the same manner as dark ones as reported by Jakopic et al. (2007) and Guerrero et al. (2002). As the fruit skin colour (especially the background colour) is also correlated with the fruit ripening, so it can be concluded that the white anti-hail net can promote the ripening of the fruit. Measurements on the red side of the fruit showed better red colouration in the fruit grown under the red net than in the fruit grown under the white net (Figure 2). This was probably caused by passing more UV-B sunlight through red, and so it causes better red colouration, as it was shown in previous studies that UV-B light promotes the red colouration of apples (Peng and Moriguchi, 2013).

All the nets have shown very distinct total colour differences in comparison with the control fruit. There were no significant differences in total coloured varieties among different coloured nets on both green and red sides of fruit (Figure 3 and 4). This lack of significant differences suggests that there are no differences in the total colour varieties in the fruit grown under the various coloured nets, although there are visible differences seen by the eye. And so, this parameter should be more investigated in the future researches to distinct if this lack of significance is caused by high variations in measured samples, or there are no consistent results of this parameter under the various coloured nets.

Colour indices shown as $a^{*} / b^{*}$ ratio are recommended for fresh apple (Pathare et al., 2012). Regarding to the colour indices, the fruit grown without the net or under the various coloured nets did not show any significant difference (data not shown).

Fruit colouration classes (0-25\%, $25-50 \%, 50-75 \%$ and $75-100 \%$ of skin colouration) indicated some differences between the nets. The white net had more fruit in $25-50 \%$ colouration class than the control, and it had less fruit in the class $50-75 \%$ than the control and the red net (Figure 5). This shows that netting significantly affects the intensity of the skin colouration. The colouration parameter is better than the individual colour indices since it is important factor that affects consumer's preferences. Colouration index (Figure 6) takes previous mentioned classes into 


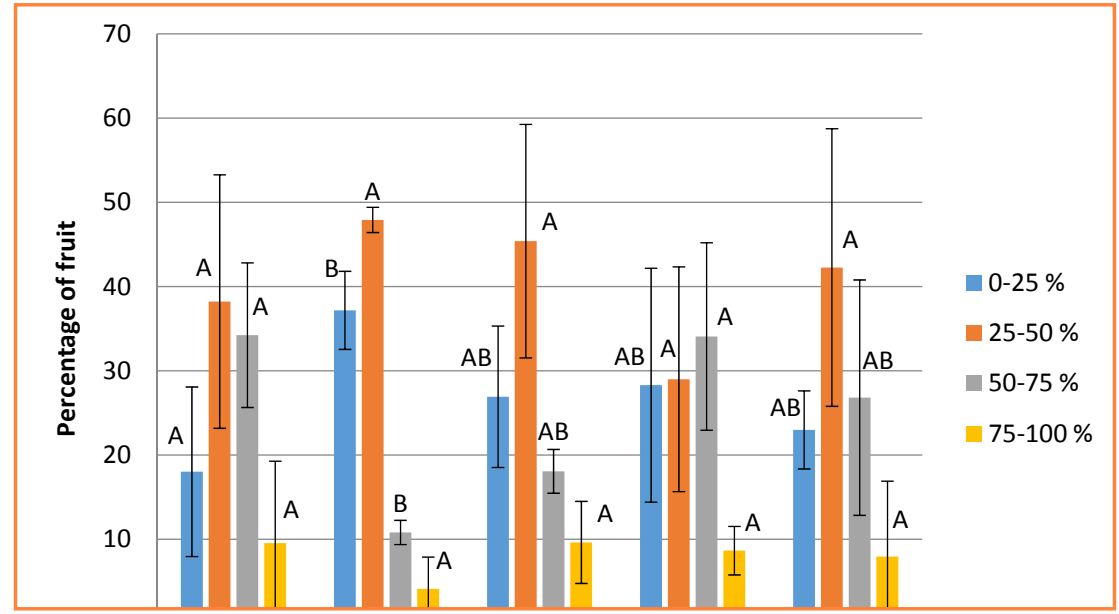

Figure 5 Fruit colouration of the apple cv. 'Braeburn' grown under the white, yellow, red and Stop Drosophila Normal nets and without the net' Note: Means inside one colouration class followed with the same letter are not significantly different (LSD test at $p \leq 0.05$ level

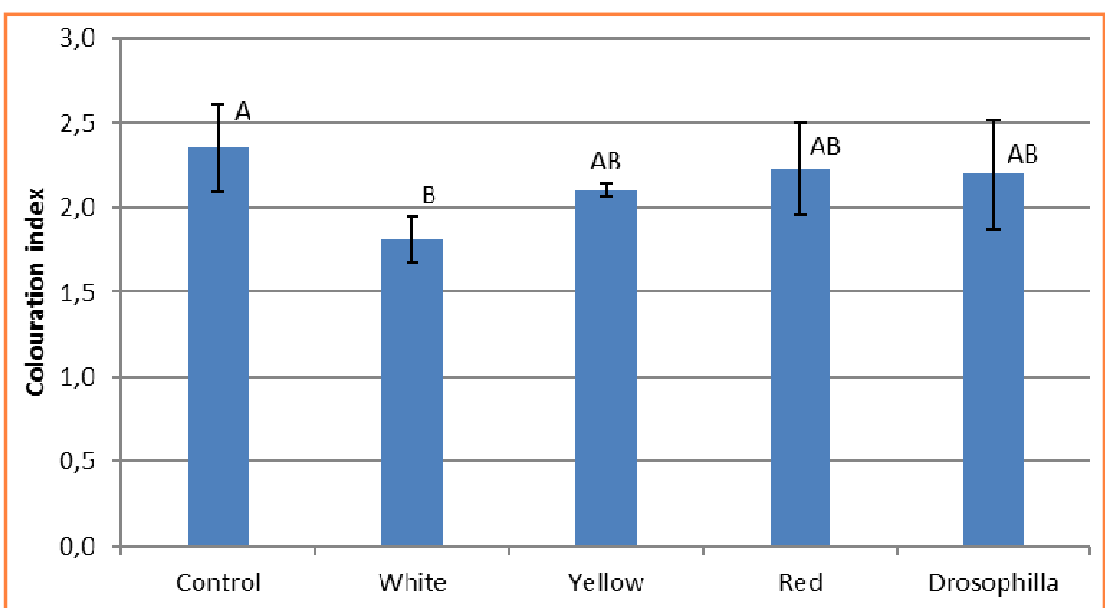

Figure 6 Colouration index of apple cv.'Braeburn' grown under the white, yellow, red and Stop Drosophila Normal nets and withoutthe net'

Note: Means followed with the same letter are not significantly different (LSD test at $p \leq 0.05$ level)

consideration, but it puts them in more objective surroundings, and also it shows that the fruit grown under the white net were less coloured than the control fruit. Significant differences in the colouration index among nets were not found.

\section{Conclusion}

Changes in fruit colour among the fruit grown under the various coloured nets did not show any significance. It seems that the usage of different coloured anti-hail net has some impact on colouration of 'Braeburn' apple, but not as much as it was expected. The most significant differences were noticed between the fruit grown under the white nets and the control fruit. The white net promotes colour change and ripening, but it affects red colouration negatively. This result shows some contradiction and needs to be studied further. Some accepted colour parameters such as $a^{*} / b^{*}$ ratio are not appropriate for describing colour changes in 'Braeburn' apple in this study.

\section{Acknowledgments}

This study was carried out with a contribution of the LIFE financial instrument of the European Union for the project "Low pesticide IPM in sustainable and safe fruit production" (Contract No. LIFE13 ENV/HR/000580).

\section{References}

ABBOTT, J. A. 1999. Quality measurement of fruits and vegetables. In Postharvest Biology and Technology, vol. 15, no. 3, pp. 207-225. ARTHURS, S. P. - LACEY, L. A. - MILICZKY, E. R. 2007. Evaluation of the codling moth granulovirus and spinosad for codling moth control and impact on non-target species in pear orchards. In Biological Control, vol. 41, no. 1, pp. 99-109.

GUERRERO, V. M. - OROZCO, J. A. - ROMO, A. GARDEA, A. A. - MOLINA, F. J. - SASTRÉ, B. MARTINEZ, J. J. 2002. The effect of hail nets and ethephon on color development of 'Redchief Delicious' apple fruit in the highlands of Chihuahua, Mexico. In Journal of the American Pomological Society, vol. 56, no. 3, pp. 132-135. IGLESIAS, I. - SALVIA, J. - TORGUET, L. - CABUS, C. 2002. Orchard cooling with overtree microsprinkler irrigation to improve fruit colour and quality of 'Topred Delicious' apples. In Scientia Horticulturae, vol. 93, pp. 39-51. JAKOPIC, J. - VEBERIC, R. - STAMPAR, F. 2007. The effect of reflective foil and hail nets on the lighting, color and anthocyanins of 'Fuji' apple. In Scientia Horticulturae, vol. 115, no. 1, pp. 40-46. NAGY, A. - RICZU, P. - TAMÁS, J. 2016. Spectral evaluation of apple fruit ripening and pigment content alteration. In Scientia Horticulturae, vol. 201, pp. 256-264.

PATHARE, P. B. - OPARA, U. L. - AL-SAID, F. A. J. 2012. Colour Measurement and Analysis in Fresh and Processed Foods: A Review. In Food and Bioprocess Technology, vol. 6, no. 1, pp. 36-60. PENG, T. - MORIGUCHI, T. 2013. The molecular network regulating the coloration in apple. In Scientia Horticulturae, vol. 163, pp. 1-9.

SAUPHANOR, B. - SEVERAC, G. - MAUGIN, S. TOUBON, J. F. - CAPOWIEZ, Y. 2012. Exclusion netting may alter reproduction of the codling moth (Cydia pomonella) and prevent associated fruit damage to apple orchards. In Entomologia Experimentalis et Applicata, vol. 145, no. 2, pp. 134-142.

SAURE, M. C. 1990. External control of anthocyanin formation in apple: a review. In Scientia Horticulturae, vol. 42, no. 3, pp. 181-218. SOLOVCHENKO, A. E. - CHIVKUNOVA, O B. - MERZLYAK, M. N. - GUDKOVSKY, V. A. 2005. Relationships between chlorophyll and carotenoid pigments during on- and offtree ripening of apple fruit as revealed nondestructively with reflectance spectroscopy. In Postharvest Biology and Technology, vol. 38, no. 1, pp. 9-17.

UBI, B. E. - HONDA, C. - BESSHO, H. - KONDO, S. - WADA, M. - KOBAYASHI, S. - MORIGUCHI, T. 2006. Expression analysis of anthocyanin biosynthetic genes in apple skin: Effect of UV-B and temperature. In Plant Science, vol. 170, no. 3, pp. 571-578.

WITZGALL, P. - BÄCKMAN, A. C. - SVENSSON, M. - KOCH, U. - RAMA, F. - EL-SAYED, A. BRAUCHLI, J. - ARN, H. - BENGTSSON, M. LÖFQVIST, J. 1999. Behavioral observations of codling moth, Cydia pomonella, in orchards permeated with synthetic pheromone. In BioControl, vol. 44, pp. 211-237.

ZHANG, M. - ZHANG, G. - YOU, Y. -YANG, C. - LI, P. - MA, F. 2016. Effects of relative air humidity on the phenolic compounds contents and coloration in the 'Fuji' apple (Malus domestica Borkh.) peel. In Scientia Horticulturae, vol. 201, pp. 18-23. 